\title{
Receptor Activator Nuclear KappaB Ligand Measurement
}

National Cancer Institute

\section{Source}

National Cancer Institute. Receptor Activator Nuclear KappaB Ligand Measurement. NCI Thesaurus. Code C117852.

The determination of the amount of receptor activator nuclear kappaB ligand present in a sample. 